PENANGGUNG JAWAB

Dekan Fakultas Ilmu Tarbiyah dan Keguruan

REVIEWER

Ani Cahyadi

Universitas Islam Negeri Antasari Banjarmasin, Indonesia

Imam Rofiki

Universitas Islam Negeri Maulana Malik Ibrahim Malang, Indonesia

Nuril Mufidah

Universitas Islam Negeri Maulana Malik Ibrahim Malang, Indonesia

Nuri Wuryandani

Universitas Negeri Yogyakarta, Indonesia

Muhammad Walid

Universitas Islam Negeri Maulana Malik Ibrahim Malang, Indonesia

Wahid Murni

Universitas Islam Negeri Maulana Malik Ibrahim Malang, Indonesia

EDITOR IN CHIEF

M. Irfan Islamy

Universitas Islam Negeri Maulana Malik Ibrahim Malang, Indonesia

SECTION EDITOR

Abdul Fattah

Universitas Islam Negeri Maulana Malik Ibrahim Malang, Indonesia

Galih Puji Mulyanto

Universitas Islam Negeri Maulana Malik Ibrahim Malang, Indonesia

Dewi Nur Suci

Sekolah Tinggi Agama Islam Kediri, Indonesia

Dwi Sulistiani

Universitas Islam Negeri Maulana Malik Ibrahim Malang, Indonesia

LAYOUT EDITOR

Rendi Setyo Marandi

Universitas Islam Negeri Maulana Malik Ibrahim Malang, Indonesia 
ii | P a g e

PEDOMAN TRANSLITERASI

\begin{tabular}{|c|c|c|c|}
\hline Arab & Latin & Arab & Latin \\
\hline 1 & $a$ & ض & $\mathrm{dh}$ \\
\hline ب & $\mathrm{b}$ & $b$ & th \\
\hline ت & $t$ & b & zh \\
\hline$ث$ & ts & $\varepsilon$ & 1 \\
\hline ج & $\mathrm{j}$ & $\dot{\varepsilon}$ & gh \\
\hline$\tau$ & $\mathrm{h}$ & ف & $\mathrm{f}$ \\
\hline$\dot{\tau}$ & kh & ق & $q$ \\
\hline د & d & ك & $\mathrm{k}$ \\
\hline ذذ & $\mathrm{dz}$ & J & 1 \\
\hline נ & $r$ & م & $\mathrm{m}$ \\
\hline j & $\mathrm{Z}$ & ن & $\mathrm{n}$ \\
\hline س & S & 9 & $\mathrm{~W}$ \\
\hline ش & sy & هـ & $\mathrm{h}$ \\
\hline ص & sh & ى & $\mathrm{y}$ \\
\hline
\end{tabular}


DAFTAR ISI

i

PENANGGUNG JAWAB

i

REVIEWER

i

EDITOR IN CHIEF

i

SECTION EDITOR

i

LAYOUT EDITOR

ii

PEDOMAN TRANSLITERASI

iii

DAFTAR ISI

01-12

Pembelajaran Bahasa Arab di MIN 13 Kabupaten Banjar Kalimantan Selatan

Mahmudah

Universitas Islam Negeri Antasari Banjarmasin, Indonesia

13-23

Keefektifan Model Make A Match dalam Pembelajaran Matematika Siswa Kelas VI

Sekolah Dasar di Kecamatan Marioriwawo

Andi Kaharuddin

Universitas Lakidende Unaaha, Indonesia

24-39

Konsepsi Penerapan Keterampilan Proses Sains (KPS) dan Sikap Ilmiah Dalam Desain Pengembangan Modul Panduan Eksperimen Ipa SD/MI

Ida Fiteriani ${ }^{1}$ dan Baharuddin ${ }^{2}$

1,2Universitas Islam Negeri Raden Intan Lampung, Indonesia

40-45

Pengembangan Multimedia Pembelajaran Interaktif Materi Pokok Sistem Tata Surya Untuk Siswa Kelas VI SD

Vannisa Aviana Melindaㄹ, Dimas Sambung'2, Dian Eka Aprilia Fitria Ningrum³ ${ }^{3}$ Imroatul Hayyu Erfantinni ${ }^{4}$, Roiyan One Febriani ${ }^{5}$

1,2,3,4,5Universitas Islam Negeri Antasari Banjarmasin Indonesia, Indonesia

46-52

Pengembangan Media Pembelajaran Pop-Up Berbasis Sains Kelompok B RA Raden Fatah Podorejo

Dessy Putri Wahyuningtyas ${ }^{1}$, Faizatun Na'fiah

1,2Universitas Islam Negeri Maulana Malik Ibrahim Malang, Indonesia

PEDOMAN PENULISAN

UCAPAN TERIMAKASIH

Vol. 11 No. 1, Desember 2018

Madrasah homepage: http://ejournal.uin-malang.ac.id/index.php/madrasah/index 


\title{
KONSEPSI PENERAPAN KETERAMPILAN PROSES SAINS (KPS) DAN SIKAP ILMIAH DALAM DESAIN PENGEMBANGAN MODUL PANDUAN EKSPERIMEN IPA SD/MI
}

\author{
Ida Fiteriani' ${ }^{1}$ dan Baharuddin ${ }^{2}$ \\ Universitas Islam Negeri Raden Intan Lampung \\ 1ida.fiteriani@radenintan.ac.id; 2baharudinpgmi@radenintan.ac.id
}

\begin{abstract}
DOI: $10.18860 /$ madrasah.v11i1.5801
Abstrak. Penelitian ini beranjak dari persoalan minimnya ketersediaan buku ajar (modul) IPA berbasis pada pengembangan KPS dan sikap ilmiah siswa. Umumnya buku-buku teks atau buku paket yang sering digunakan guru atau siswa lebih menekankan pada penguasaan konsep IPA (scientific knowledge), sedangkan keterampilan proses sains (scienific process) serta sikap ilmiah apa yang ingin ditumbuhkembangkan tidak terumuskan dengan jelas dan detail, sehingga berdampak pada aktivitas dan pemperolehan hasil belajar siswa. Berdasarkan deskripsi permasalahan di atas, karenanya tujuan penelitian dan pengembangan (Research and Development) ini untuk menghasilkan produk berupa modul eksperimen IPA untuk SD/MI yang berbasis pada KPS dan sikap ilmiah pada materi Sistem Peredaran Darah Manusia. Model yang digunakan merujuk pada Borg and Gall. Untuk menilai kelayakan modul dilakukan validasi kepada para ahli (ahli materi, ahli media, dan ahli bahasa) dan juga melibatkan praktisi pendidikan. Untuk menilai kemenarikan modul dilakukan uji coba, yang dimulai dari kelompok kecil lalu pada kelompok besar. Selanjutnya, proses analisis data menggunakan teknik kuantitatif dan kualitatif. Hasil penelitian Research and Development $(R \& D)$ ini adalah 1) Langkah pengembangan dimulai dengan menganalisis potensi dan masalah, mengumpulkan data/informasi, mendesain produk, memvalidasi produk, merevisi produk, melakukan uji coba kelayakan produk, dan merevisi produk kembali. 2) Berdasarkan hasil validasi dan ujicoba kelayakan, pengembangan modul eksperimen IPA untuk SD/MI berbasis pada KPS dan sikap ilmiah pada materi Sistem Peredaran Darah Manusia berhasil memenuhi tingkat kelayakan dan kemenarikan, sehingga dapat dapat digunakan sebagai bahan ajar dalam pembelajaran IPA di SD/MI.
\end{abstract}

Kata Kunci. Modul eksperimen IPA, scientific process, and scientific attitude

Abstract. . This research moved from the problem of the lack of availability of science books (modules) based on the development of science process skills (scienific process) and scientific attitude of students. Generally textbooks that are often used by teachers or students emphasize mastery of science concepts (scientific knowledge), while science process skills (scienific process) and what scientific attitudes to be developed are not clearly defined and detailed, so that the impact on activity and acquisition of student learning outcomes. Based on the description of the above problems, the purpose of this research and development is to produce a product in the form of an experimental module for science in elementary school that based on science process skills (scienific process) and scientific attitudes, expecially in term : Human Circulatory System. The model used refers to Borg and Gall. To assess the feasibility of the module, validation was carried out by experts (material experts, media experts, and linguists) and also involved education practitioners. To assess the attractiveness of the module a trial was conducted, which began with a small group and then in a large group. Furthermore, the process of data analysis uses quantitative and qualitative techniques. The research and development $(R$ \& D) results are 1) The development step begins with analyzing potential and problems, collecting data/information, designing products, validating products, revising products, conducting product feasibility trials, and revising products again. 2) Based on the results of validation and feasibility tests, the development of the science module experiment for SD / MI based on science process skills (scienific process) and scientific attitudes in the term of the Human Circulatory System successfully meet the level of feasibility and attractiveness, therefore it can be used as teaching material in science learning in elementary school (SD/MI)

Keywords. Experimental modules for science; scientific process; scientific attitude, Human Circulatory System

Vol. 11 No. 1 Desember 2018

Madrasah homepage: http://ejournal.uin-malang.ac.id/index.php/madrasah/index 


\section{MADRASAH}

Jurnal Pendidikan dan Pembelajaran Dasar

p ISSN: 1979-5599 | e ISSN: 2502-194X

P a ge

\begin{tabular}{ll|l}
\hline Received $: 12$ Desember 2018 & Approved $: 22$ Desember 2018 \\
Reviesed $: 22$ Desember 2018 & Published :31 Desember 2018 \\
\hline
\end{tabular}

Copyright (C) Madrasah Jurnal Pendidikan dan Pembelajaran Dasar. All Right Reserved.

This is an open-access article under the CC BY-NC-ND license

(http://creativecommons.org/licenses/by-nc-nd/4.0/).

Correspondence Address: ida.fiteriani@radenintan.ac.id

\section{A. PENDAHULUAN.}

\section{Latar Belakang}

Hakikat pembelajaran IPA terdiri dari tiga komponen utama yang tidak terpisahkan yaitu, mengajarkan konsep/materi sains (scientific knowledge), proses penemuan materi sains (scientific process), dan membentuk sikap ilmiah setelah pembelajaran sains (scientific attitude). Tanpa ketiganya, pengajaran IPA yang diberikan tidak dapat berlangsung secara utuh membentuk siswa yang berpandangan dan bertindak ilmiah.

Terkait dengan itu, Carin and Sund (1989:5) menyatakan "Science has three major element: attitudes, processes or methods, and product". Menurut pendapat ini, sains sebagai produk diartikan sains sebagai tubuh pengetahuan yang terorganisir terdiri dari fakta, konsep, hukum, teori, dan generalisasi, yang dalam proses pembelajaran IPA merupakan wawasan atau keilmuan, atau pengetahuan sains yang harus dipahami siswa dan menjadi langkah awal untuk mampu melakukan eksperimen sains. Kemudian, pembelajaran sains sebagai proses diartikan berbagai keterampilan proses yang harus dikuasai siswa, diantaranya kemampuan mengobservasi, mengklasifikasi, mengukur, memprediksi, melakukan percobaan/eksperimen sederhana, mengkomunikasikan, dan menarik kesimpulan. Keterampilan proses ini menjadi sangat penting untuk melakukan ekperimen/praktikum IPA. Wawasan IPA tanpa keterampilan proses sains yang memadai tidak berarti apa-apa.

Terakhir pembelajaran sains sebagai pembentukan sikap ilmiah, diartikan beberapa sikap ilmiah yang melekat kuat harus tertanam dalam diri siswa layaknya para ilmuwan sains ketika mereka melakukan eksperimen (percobaan) sains (Trianto, 2013:135). Sikap ilmiah itu seperti memiliki rasa ingin tahu yang besar, pantang menyerah, berani mencoba, teliti, cermat, hati-hati dalam bertindak, sabar, berjiwa besar atau terbuka terhadap pendapat/kritik orang lain serta luwes atau mampu bekerja sama dalam tim. Sikap ilmiah ini terbentuk hasil manifestasi dari pemahaman konsep IPA dan keterampilan proses yang terjewantah dalam perbuatan saat pelaksanaan eksperimen.

Pelaksanaan pembelajaran IPA yang didesain dengan kegiatan eksperimen (praktikum IPA) menjadi langkah metodis yang sangat efektif untuk menumbuhkuatkan tiga aspek IPA tersebut. Ini selaras dengan pernyataan Carin dan Sund (1985), yang mengatakan sains itu sebenarnya "sistem pengetahuan alam semesta yang diperoleh melalui pengumpulan data yang dilakukan dengan observasi dan eksperimen."(Depdiknas, 2007:3) Dipertegas pula dengan pendapat Powler yang menatakan bahwa sains merupakan "ilmu yang berhubungan dengan gejala-gejala alam dan kebendaan yang sistematis yang tersusun secara teratur, berlaku umum yang berupa kumpulan dari hasil observasi dan eksperimen."(Udin S. Winataputra, 1992:122).

Lebih lanjut, Koballa dan Chiapetta (2010: 105) menyebutkan bahwasanya IPA sebagai a way of thinking. Hal ini berarti mengajarkan IPA harus mengembangkan proses ilmiah siswa dalam membentuk pola fikir kritis dan analitis agar dapat berkonstribusi memberikan pemecahan masalah terhadap materi-materi IPA yang disajikan lewat kegiatan penyelidikan atau percobaan (eksperimen). Substansinya, proses belajar memahami sains sebenarnya merupakan produk eksperimental, maksudnya hasil bergelut dari aktifitas mencoba dan mencoba secara ilmiah. 
Berdasarkan hasil pelaksanaan Penelitian dan Pengabdian tentang Workshop Pembelajaran Sains Menggunakan Barang-barang Bekas bagi Guru-guru MI se Kota Bandar Lampung (2016) diperoleh kesimpulan kemampuan guru melakukan eksperimen IPA dalam proses KBM IPA di SD/MI masih perlu peningkatan dan pengembangan lebih lanjut. Hal ini terlebih terlihat pada praktikum materi Sistem Peredaran Darah Manusia dan Rotasi \& Revolusi Bumi serta Pengaruhnya. Di mana sebanyak 24 guru dari 30 peserta guru yang hadir mengakui sangat kesulitan mengembangkan media untuk menjelaskan materi tersebut. Hasil ini tentunya berpengaruh terhadap proses pengajaran menjadi lebih banyak dilakukan dengan penyampaian secara lisan (ceramah), demonstrasi dengan media gambar yang tertera dalam buku paket, dan tanpa menggunakan alat peraga sebagai alat bantu pembelajaran.

Bagian pemecahan masalah di atas, diantaranya dengan menyediakan bahan ajar yang dapat menjadi panduan eksperimen siswa. Sebab, berdasarkan wawancara peneliti dengan salah satu guru di kelas V dan Kepala Sekolah, diperoleh informasi bahwasaya buku paket IPA yang tersedia lebih banyak berisi penyajian konsep-konsep IPA, sehingga lebih dominan berisi tentang aspek wawasan, keilmuan, atau pengetahuan IPA (scientific knowledge). Sementara yang diharapkan penyajian materi dibarengi dengan bagaimana cara meningkatkan keterampilan proses IPA atau KPS siswa melalui kegiatan eksperimen yang dilakukan siswa. Selain itu, dari sisi tampilan juga terdapat beberapa kelemahan seperti ilustrasi/gambar penyajian eksperimen kurang menarik, atau gambar yang tersaji kurang jelas dan tidak berwarna. Sementara siswa usia SD umumnya lebih menyukai buku yang memiliki gambar, berwarna, jelas, dan menarik.

Dengan demikian, persoalan yang real yang kini sedang dihadapi sekolah adalah proses pembelajaran IPA yang dilakukan selama ini belum sepenuhnya berorientasi pada pengembangan scientific knowledge, scientific process, dan scientific attitude secara seimbang dan terpadu. Proses pembelajaran yang dilaksanakan guru lebih ditekankan pada pemberian materi secara klasikal, sangat jarang melaksanakan kegiatan eksperimen, dan sangat minim menggunakan alat peraga IPA yang real dan bervariasi. Beranjak dari permasalahan ini, perlu adanya panduan praktik atau modul eksperimen IPA yang berbasis pada pengembangan KPS dan sikap ilmiah. Ketersediaan modul ini dapat menjadi acuan dan bahan ajar bagi guru dalam mengajar IPA. Karena tidak dapat dihindari bahwa tercapainya misi peningkatan mutu pendidikan sains di SD/MI erat kaitannya dengan ketersediaan bahan ajar yang memadai.

\section{B. METODE PENELITIAN}

Jenis penelitian yang digunakan adalah penelitian dan pengembangan (Research and Development). Penelitian dan pengembangan ( $\mathrm{RnD}$ ) bertujuan untuk menghasilkan produk tertentu dan menguji keefektifan produk tersebut (Sugiyono, 2013:407). Desain pengembangan menggunakan model Borg and Gall. Terdapat 10 langkah pengembangan, namun yang teraplikasi hanya 7 (tujuh) langkah dikarenakan pelaksanaan penelitian tidak sampai melakukan uji efektifitas produk.

Lokasi penelitian ini bertempat di sejumlah MIN di Bandar Lampung. Teknik pengumpulan data menggunakan observasi, wawancara, tes praktek, kuesioner (angket), dan analisis dokumentasi. Merujuk pada itu, peneliti menggunakan dua jenis data yaitu yang bersifat kuantitatif dan kualitatif. Kuesioner digunakan pada saat validasi dan uji coba. Angket validasi ditujukan kepada validator ahli dan praktisi pendidikan.

Validator ahli yaitu ahli materi, ahli media, dan ahli bahasa. Validator ahli media, menilai dalam aspek kegrafikan dan penyajian modul. Aspek kegrafikan adalah aspek yang digunakan untuk memberikan penilaian terhadap ukuran, cover, dan isi modul. Aspek penyajian adalah aspek yang didalamnya mencakup teknik penyajian, pendukung penyajian, dan kelengkapan penyajian modul. Sedangkan validator ahli bahasa digunakan untuk memberi penilaian dalam aspek kesesuaian bahasa dan kalimat yang digunakan dalam pengembangan modul sesuai dengan tingkat perkembangan berfikir siswa serta kesesuaianya dengan kaidah bahasa Indonesia yang baku atau sesuai EYD. 


\section{MADRASAH}

Jurnal Pendidikan dan Pembelajaran Dasar

p ISSN: 1979-5599 | e ISSN: 2502-194X

Jumlah item pertanyaan yang diajukan kepada validator ahli materi ada 50 item, validator ahli media ada 22 item, dan validator ahli bahasa ada 15 item. Sedangkan praktisi pendidikan adalah guru MI. Tujuannya, menilai dalam aspek isi, alat peraga, penggunaan ilustrasi (gambar, tabel, dan peta konsep), metode penyajian, evaluasi dan penampilan modul eksperimen IPA untuk SD/MI secara keseluruhan. Item pertanyaan yang diajukan kepada praktisi pendidikan ada 20 item.

Sedangkan pada saat uji coba, angket diberikan pada siswa kelas V, ada 15 item pertanyaan yang diajukan Skor penilaian validator dan praktisi pendidikan menggunakan skala Likert, yaitu dengan kategori "Sangat Baik (4), Baik (3), Cukup (2), dan Tidak Baik (1). Sedangkan penilaian siswa karena yang diukur adalah tingkat kemenarikan mereka, maka penilaian juga menggunakan skala Likert, namun dengan kategori Sangat Menarik (Skor 4), Menarik (skor 3), Kurang Menarik (Skor 2), dan Tidak Menarik (Skor 1).

Data kualitatif yaitu data berupa pendiskripsian dalam bentuk informasi kalimat yang diperoleh dari hasil survey pendahuluan, validasi produk dari para ahli maupun praktisi pendidikan (guru), serta respon kemarikan dari siswa sebagai pengguna. Data kualitatif pada tahap validasi produk, berupa pendiskripsian kualitatif hasil mengolah data dari tanggapan ataupun saran yang diberikan oleh validator, baik validator ahli materi, ahli media, ahli bahasa, maupun praktisi pendidikan (guru). Sedangkan deskripsi kualitatif dari siswa merupakan pengolahan data hasil dari respon kemenarikan mereka terhadap Modul Eksperimen IPA yang peneliti kembangkan.

Teknik analisis data pada penelitian ini juga menggunakan teknik analisis kuantitatif dan kualitatif. Teknik kuantitatif diperlukan untuk menghitung hasil skor penilaian yang diberikan validator, praktisi pendidikan, maupun siswa. Hasil perhitungan dari validator dan praktisi pendidikan nanti akan dicari rata-ratanya dan dikonversikan ke pernyataan untuk menentukan kevalidan dan kelayakan modul. Kriteria mengacu pada pendapat Novitasari (2014:134), yaitu:

Tabel 1. Kriteria Penilaian Validasi (dimodifikasi)

\begin{tabular}{|c|c|c|}
\hline Skor Kualitas & Kriteria Kelayakan & Keterangan \\
\hline $3,26<\bar{X} \leq 400$ & Valid & Tidak Revisi \\
\hline $2,51<\bar{X} \leq 3,26$ & Cukup Valid & Revisi Sebagian \\
\hline $1,76<\bar{X} \leq 2,51$ & Kurang Valid & $\begin{array}{c}\text { Revisi Sebagian dan } \\
\text { Pengkajian Ulang Materi }\end{array}$ \\
\hline $1,00<\bar{X} \leq 1,76$ & Tidak Valid & Revisi Total \\
\hline
\end{tabular}

Selanjutnya penilaian terkait respon kemenarikan oleh siswa juga akan dicari rataratanya dan dikonversikan ke pernyataan untuk menentukan kemenarikan modul. Kriteria penilaian juga mengacu pada pendapat Novitasari (2014:134), sebagai berikut:

Tabel 2. Kriteria Penilaian Kemenarikan(dimodifikasi)

\begin{tabular}{|c|c|}
\hline Skor Kualitas & Pernyatan Aspek Kemenarikan \\
\hline $3,26<\bar{X} \leq 4,00$ & Sangat Menarik \\
\hline $2,51<\bar{X} \leq 3,26$ & Menarik \\
\hline $1,76<\bar{X}$ & Kurang Menarik \\
\hline $1,00<\bar{X} \leq 1,76$ & Sangat Kurang Menarik \\
\hline
\end{tabular}




\section{HASIL PENELITIAN}

Produk utama yang dihasilkan dari penelitian ini adalah Modul Eksperimen IPA untuk SD/MI yang Berbasis pada KPS dan Sikap Ilmiah pada Materi Sistem Peredaran Darah Manusia. Penelitian dan pengembangan ini dilakukan dengan prosedur pengembangan menurut Borg and Gall yang dalam penerapannya telah dilakukan modifikasi dan penyesuaian sesuai kebutuhan penelitian. Dengan merunut pada masalah penelitian ini, maka 7 (tujuh) tahapan yang ditempuh dalam penelitian ini yaitu:

\section{Potensi dan Masalah}

Penelitian Research and Development (RED) ini diawali dengan melakukan identifikasi potensi dan masalah terkait mutu pembelajaran IPA selama ini di SD/MI. Sebagaimana peneliti telah paparkan sebelumnya bahwa data awal penelitian ini merujuk pada hasil pelaksanaan penelitian dan pengabdian tentang workshop pembelajaran sains menggunakan barang-barang bekas bagi guru-guru MI se Kota Bandar Lampung, tahun 2016. Tim Pengabdian terdiri dari IF, NW, dan DAS. Hasil pelaksanaan pengabdian menyimpulkan bahwa banyak guru yang belum mengajarkan IPA dengan melakukan eksperimen menggunakan alat peraga, terutama yang berbahan barang bekas. Terkhusus pada materi sistem peredaran darah pada manusia, para guru masih banyak yang menemui kendala. Alasan yang utama yang mengemuka adalah sulitnya materi yang diajarkan dan media/alat peraga yang dibuat juga sulit.

Untuk memperkuat temuan data awal tersebut, peneliti melakukan observasi terkait bagaimana pelaksanaan pembelajaran IPA di SD/MI selama ini di kelas 5. Juga menguatkan data dengan melakukan wawancara dengan Kepala Sekolah dan guru, dan melakukan tes praktek untuk mengetahui sejauh mana kemampuan eksperimen siswa terhadap materi Sistem Peredaran Darah pada Manusia yang akan dikembangkan. Keseluruhan data yang terkumpul tersebut, peneliti gunakan sebagai bahan untuk menyusun Modul Eksperimen IPA untuk SD/MI yang Berbasis pada KPS dan Sikap Ilmiah pada Materi Sistem Peredaran Darah Manusia.

Beranjak dari permasalahan yang peneliti temukan saat studi pendahuluan atau prasurvey tersebut, potensi (sumber-sumber daya) sekolah apa saja yang dapat diberdayakan, dioptimalkan, atau dimanfaatkan guna mengatasi masalah tersebut sangatlah besar dalam rangka meminimalisir permasalahan di kelas tersebut, seperti keterbukaan pihak sekolah dan keinginan untuk maju, terutama pihak kepala sekolah dan guru, sangat terbuka saat peneliti berdiskusi mengenai masalah ini.

Kompetensi guru juga sudah sangat memadai karena umumnya mereka sudah berstatus PNS dan berlatar belakang pendidikan yang sesuai. Kemudian, fasilitas sekolah berupa buku, alat-alat, ataupun sumber belajar lainnya cukup memadai untuk menunjang pemecahan masalah. Selain itu, lingkungan sekolah juga sangat kondusif dan menyenangkan, sehingga diproyeksikan pengembangan Modul Eksperimen IPA untuk SD/MI yang Berbasis pada KPS dan Sikap Ilmiah pada Materi Sistem Peredaran Darah Manusia dapat terwujud dengan baik sesuai dengan rencana karena mendapat dukungan dari pihak sekolah.

\section{Mengumpulkan Data/Informasi}

Berdasarkan hasil identifikasi masalah di atas, selanjutnya peneliti melaksanakan pengumpulan data dan informasi guna melakukan need assesment agar perencanaan pembuatan modul ini sesuai dengan kebutuhan real sekolah. Dalam proses ini, peneliti juga mencoba mentelaahnya dari perspektif teori (mengkaji dari berbagai referensi buku) dan dari hasil-hasil penelitian terdahulu yang relevan. Berdasarkan pentelaahan diketahui dalam merencanakan modul harus sesuai dengan materi yang dianggap sulit, sehingga harus dipilih materi yang dianggap prioritas.

Selain itu, penyampaian materipun harus disesuaikan dengan objek ajarnya atau peserta didik. Untuk itu harus dipahami bagaimana tahapan pertumbuhan dan perkembangannya peserta didik khususnya yang masih duduk di SD/MI, serta yang terpenting mengajarkan IPA harus sesuai dengan karakteristik mata pelajaran itu sendiri, yang mana dalam hal ini mengajak 


\section{MADRASAH}

Jurnal Pendidikan dan Pembelajaran Dasar

p ISSN: 1979-5599 | e ISSN: 2502-194X

P a g e

siswa untuk mengalami langsung pada objek materi yang sedang dipelajarinya dengan cara melakukan eksperimen.

Beranjak dari data itu, maka dalam menyusun modul IPA, peneliti harus mengembangkan scientific knowledge, scientific process, dan scientific attitude siswa secara berimbang, serta memahami bahwa dalam tahapan perkembangan kognitif, siswa SD/MI menurut Jean Piaget sedang berada pada fase operasional konkrit. Ciri umum yang sangat menonjol adalah dalam proses pembelajaran adalah anak sudah mampu melakukan aktivitas logis dan mampu menyelesaikan masalah dengan baik, tetapi masih sulit mengungkapkan sesuatu yang masih tersembunyi. Implikasinya dalam pembelajaran IPA, anak-anak kelas SD/MI tidak akan dapat memahami oprasi (logis) dalam konsep IPA tanpa dibantu oleh benda-benda kongkrit/nyata. Dalam artian, dalam belajar IPA mereka sangat memerlukan benda-benda kongkrit, contoh penggunaan alat peraga sederhana dalam menyelesaikan masalah. Dengan demikian, sangat jelas bahwa dalam menyusun modul eksperimen IPA, di dalamnya harus disajikan pula bagaimana merancang alat peraga sederhana guna mendukung kegiatan percobaan (eksperimen) IPA yang siswa lakukan.

Selanjutnya, berdasarkan pendapat Bassett, Jacka, dan Logan (dalam Sumantri dan Permana, 2001:11) secara umum karakteristik anak usia sekolah dasar adalah:

a. Mereka secara alamiah memiliki rasa ingin tahu yang kuat dan tertarik akan dunia sekitar yang mengelilingi diri mereka sendiri;

b. Mereka senang bermain dan lebih suka bergembira/riang;

c. Mereka suka mengatur dirinya untuk menangani berbagai hal, mengeksplorasi suatu situasi dan mencobakan usaha-usaha baru;

d. Mereka biasanya tergetar perasaannya dan terdorong untuk berprestasi sebagaimana mereka tidak suka mengalami ketidakpuasan dan menolak kegagalan-kegagalan;

e. Mereka belajar secara efektif ketika mereka merasa puas dengan situasi yang terjadi;

f. Mereka belajar dengan cara bekerja, mengobservasi, berinisiatif, dan mengajar anak-anak lainnya.

Berdasarkan pendapat ahli di atas, jelaslah bahwa anak usia SD/MI suka menyelidik berbagai hal karena didorong oleh rasa ingin tahunya yang besar. Anak juga suka menjelajah, mencoba-coba, mengeksplorasi berbagai hal dan melakukan eksperimen secara langsung. Seiring dengan itu, maka desain pembelajaran yang disajikan dalam modul eksperimen IPA harus mampu memenuhi hak anak yang dalam proses belajarnya masih senang untuk bermain dan bergembira. Merujuk pada itu, sepatutnya deskripsi materi modul lebih memahami dunia anak dalam mengoptimalkan potensinya, dengan memfasilitasi lingkungan belajar yang kondusif.

Selanjutnya berdasarkan analisis kebutuhan materi pada penjajakan awal diketahui bahwa materi yang prioritas untuk diangkat/dikembangkan adalah materi tentang Sistem Peredaran Darah Manusia. Materi ini bagi sebagian siswa dianggap materi yang sulit. Dikarenakan pembahasannya yang rumit kemudian objek yang menjadi sasaran utama pengamatan tidak dapat diamati secara langsung, sehingga tingkat real/nyatanya sangat kurang dirasakan siswa. Akibatnya pula berpengaruh terhadap tingkat pemahaman siswa yang beragam.

Lebih lanjut untuk memperkuat data dan informasi, peneliti juga mengumpulkan data dari analisis dokumen, khususnya dari Rencana Pelaksanaan Pembelajaran (RPP) yang telah dibuat guru dan digunakan untuk pembelajaran IPA dengan materi sistem peredaran darah manusia. Dalam hal ini peneliti menemukan bahwa rancangan pembelajaran yang dilakukan guru lebih mengarah kepada RPP konvensional. Maksudnya, desain pembelajaran lebih didominasi dengan kegiatan berceramah, tanya jawab, demonstrasi dari guru, dan diakhiri dengan latihan atau menjawab. 
Hal tersebut terlihat dari skenario pembelajaran IPA yang didesain tidak mengarahkan secara langsung dan mendalam untuk siswa secara berkelompok bereksperimen untuk mengoptimalkan keterampilan proses sains dan sikap ilmiahnya. Melainkan lebih pada menghafal sejumlah konsep IPA. Hal tersebut, terlihat juga dari alat peraga yang digunakan untuk eksperimen, kurang menggali kreatifitas siswa untuk membuat alat peraga se-real (sekonkrit) mungkin. Sementara untuk lebih memperdalam penguasaan KPS dan sikap ilmiah khususnya pada materi sistem peredaran darah pada manusia ini, maka peran media/alat peraga yang real/nyata menjadi sangat penting, karena dapat memperjelas sajian materi dari kegiatan eksperimen yang dilakukan tersebut.

Kesimpulannya, dalam menyusun modul eksperimen IPA untuk SD/MI ini, peneliti harus mendesain pembelajaran IPA agar lebih mengarahkan siswa untuk menyelidiki secara langsung melalui kegiatan eksperimen yang dilakukannya, yang mana tentunya tetap berada di bawah bimbingan guru, namun dalam hal ini guru hanya berperan sebagai fasilitator pembelajaran bagi siswa, sehingga dari itu sesuai tujuan pembelajaran sains; pemahaman konsep siswa tergali, keterampilan proses sains (KPS)nya terlatihkan, dan sikap-sikap ilmiahnya terjewantah dalam dirinya.

\section{Desain Produk}

Pada bagian ini berisi tentang desain Modul Eksperimen IPA untuk SD/MI yang Berbasis pada KPS dan Sikap Ilmiah pada Materi Sistem Peredaran Darah Manusia, yang dimulai dari bagian awal hingga bagian akhir. Secara umum cakupannya meliputi halaman cover (judul), kata pengantar, petunjuk penggunaan modul, isi modul, evaluasi berupa uji kompetensi, dan dilengkapi dengan lampiran pendukung.

Pada bagian isi modul merupakan bagian yang sangat krusial. Pada bagian ini diawali dengan membuat bagan peta konsep dan menjelaskan Standar Kompetensi (SK) dan Kompetensi Dasar (KD) yang harus dicapai siswa pada materi sistem peredaran darah pada manusia. Selanjutnya, pemaparan dilanjutkan dengan penjelasan materi (scientific knowledge) tentang sistem peredaran darah pada manusia, baik dalam perspektif sains umum maupun sains Islam, dengan menyertakan ayat al-Quran atau hadits yang berkaitan dengan materi yang dibahas.

Kemudian dilanjutkan dengan mendeskripsikan bagaimana pelaksanaan eksperimen IPA (scientific process skills) sesuai materi yang diajar tersebut. Dalam pendeskripsiannya menunjukkan KPS yang sesuai beserta indikatornya. Tidak tertinggal pula media sains yang dimanfaatkan dalam kegiatan eksperimen tersebut. Terakhir dideskripsikan sikap ilmiah (scientific attitude) yang diharapkan terbangun pada siswa SD ketika proses eksperimen telah berlangsung.

Untuk melengkapi penyajian data, disertakan pula RPP dengan metode pembelajaran sains SD yang sesuai, lengkap dengan uji kompetensi untuk menilai ketercapaian belajar siswa. Dalam segi tampilan (lay out grafis) ditentukan jenis kertas yang sesuai (tidak terlalu tebal dan berwarna putih bersih), ukuran kertas dan font serta spasi yang pas. Diperhatikan pula struktur dan bagan penulisan, serta pemilihan gambar dan warna yang menarik.

\section{Validasi Desain Produk}

Validasi dilakukan setelah produk Modul Eksperimen IPA untuk SD/MI yang Berbasis pada KPS dan Sikap Ilmiah pada Materi Sistem Peredaran Darah Manusia, selesai dirancang. Komposisi tim validator dalam penelitian ini, meliputi validator ahli materi, ahli media, dan ahli bahasa, serta dari praktisi pendidikan. Berikut paparan hasil validasi:

a. Hasil Validasi Ahli Materi

Validator ahli materi yaitu orang yang kompeten dalam bidang IPA. Validator ahli materi terdiri dari 3 validator. Berdasarkan penilaian disimpulkan bahwa pada aspek Kelayakan Isi diperoleh nilai rata-rata 3,33 dengan kategori valid sehingga tidak perlu revisi, pada aspek Pengembangan Keterampilan Proses Sains (KPS) Siswa diperoleh nilai rata-rata 2.86 


\section{MADRASAH}

Jurnal Pendidikan dan Pembelajaran Dasar

p ISSN: 1979-5599 | e ISSN: 2502-194X

P a g e

dengan kategori cukup valid, sehingga perlu revisi sebagian, dan pada aspek Pengembangan Sikap Ilmiah Siswa diperoleh nilai rata-rata 3,03 dengan kategori cukup valid, sehingga diperlukan juga revisi sebagian. Kesimpulan penilaian dari validator ahli materi dapat dikriteriakan modul IPA yang dikembangkan termasuk kategori "Cukup Baik". Oleh karena itu, perlu revisi agar diperoleh modul dengan kiteria "Baik".

b. Hasil Validasi Ahli Media

Validator ahli media yaitu orang yang kompeten dalam bidang Komputer dan Teknologi. Validator ahli media dilakukan oleh 1 orang. Kesimpulan penilaian bahwa pada aspek Kegrafikan diperoleh nilai rata-rata 3.62 dengan kategori valid, sehingga tidak revisi dan pada aspek Penyajian diperoleh nilai rata-rata 2.71 dengan kategori cukup valid, sehingga perlu revisi sebagian. Kesimpulan penilaian dari validator ahli media bahwa modul yang dikembangkan termasuk kategori "Cukup Baik", sehingga perlu perbaikan agar modul yang dihasilkan termasuk kategori "Baik".

c. Hasil Validasi Ahli Bahasa

Validator ahli bahasa yaitu orang yang kompeten dalam bidang tata Bahasa Indonesia. Dilakukan oleh 1 orang validator. Hasil penilaian pada aspek kebahasan diperoleh nilai ratarata 3.40 dengan kategori valid, sehingga tidak revisi. Kesimpulannya bahwa modul yang dikembangkan termasuk kategori "Baik".

d. Hasil Validasi Praktisi Pendidikan

Validator dari unsur pendidikan, yaitu oleh guru dan terdiri dari 2 orang. Guru memberikan penilaian terhadap content (isi) yaitu apakah Modul Eksperimen IPA yang telah dirancang sesuai dengan silabus mata pelajaran dan penilaian terhadap konstruksi (kontruk) modul yaitu apakah telah sesuai dengan komponen-komponen yang seharusnya terdapat dalam modul. Dalam artian penilaian meliputi penilaian dalam aspek isi, alat peraga, penggunaan ilustrasi (gambar, tabel, dan peta konsep), metode penyajian, evaluasi dan penampilan modul eksperimen IPA untuk SD/MI secara keseluruhan.

Hasil penilaian pada aspek content (isi) diperoleh nilai rata-rata 3,45 dengan kategori valid, sehingga tidak revisi. Kemudian, penilaian pada aspek Construct (kerangka modul) diperoleh nilai rata-rata 3,38 dengan kategori valid juga, sehingga tidak revisi. Kesimpulan penilaian adalah modul yang dikembangkan termasuk kategori "Baik".

\section{Revisi Desain Produk}

Setelah proses validasi desain selesai dilakukan, tentunya terdapat saran masukan dari tim ahli dan praktisi pendidikan terkait modul eksperimen IPA yang peneliti kembangkan. Berikut penulis deskripsikan saran perbaikan dari validator ahli materi sekaligus hasil kegiatan revisi yang penulis lakukan. Pertama, bahwasanya dalam melakukan proses pengamatan dapat menggunakan satu atau lebih indera, mengumpulkan sebanyak-banyaknya fakta yang relevan, dan dapat memaksimalkan berbagai alat pengamatan guna mendukung dan memperlancar proses observasi. Kemudian, berdasarkan modal data/informasi tersebut, dapat digali apa hubungan timbal balik dari hasil identifikasi persamaan dan perbedaan yang dilakukan. Ciriciri kontrasknya dapat dikemukakan kembali sehingga diperoleh hasil perbandingan dan penggolongan yang sesuai.

Selanjutnya, dalam merencanakan eksperimen alat, bahan, dan sumber yang akan digunakan dipastikan kesiapannya, sehingga siswa dapat menentukan objek yang akan diteliti dan berdasar itu dapat menyusun laporan percobaan yang sesuai kemampuan berfikir siswa itu sendiri, yang mana laporan dilengkapi dengan cara membaca tabel, gambar, ataupun grafik/diagram untuk memperjelas laporan percobaan.

Selanjutnya, dalam pembentukan sikap ilmiah siswa harus lebih mendorong antusiasme siswa mencari jawaban terhadap berbagai pertanyaan yang dihadapinya. Sebab terlihat 
beberapa siswa karena pertanyaannya sangat sulit, siswa tampak menyerah atau bersikap kurang optimis dan tenang mencari solusi permasalahannya. Harus ditanamkan hambatan sebagai penyemangat untuk giat belajar. Berbekal kemampuan itu, siswa harusnya lebih berani membela fakta atas hasil penelitiannya, meskipun mendapatkan sanggahan/penolakan dari teman-temannya.

Dalam hal ini, caranya diantaranya untuk menguatkan pendapat dengan mengutip pendapat orang lain dan menyebutkan siapa yang berpendapat atau menghasilkan karya itu. Dengan demikian, ini berarti siswa telah menjalankan tugasnya dengan sebaik-baiknya dan lapang/senang hati menerimanya.

Saran dan koreksi di atas, kemudian ditindaklanjuti dengan melakukan perbaikan. Hasil perbaikan kemudian diajukan lagi kepada validator untuk dilakukan validasi ulang. Hasil validasi ahli materi yang dilakukan oleh 3 validator disimpulkan bahwa pada aspek Kelayakan Isi diperoleh nilai rata-rata 3,33 dengan kategori valid sehingga tidak perlu revisi, pada aspek Pengembangan Keterampilan Proses Sains (KPS) Siswa diperoleh nilai rata-rata 3.28 dengan kategori valid, sehingga tidak perlu revisi, dan pada aspek Pengembangan Sikap Ilmiah Siswa diperoleh nilai rata-rata 3,31 dengan kategori valid, sehingga juga tidak perlu revisi. Nilai ratarata tersebut menyatakan modul IPA yang dikembangkan sudah termasuk kategori "Baik".

Selanjutnya, hasil validasi dari ahli media juga diperoleh saran perbaikan, namun hanya sedikit, yaitu menyisipkan ruang yang cukup pada modul sehingga siswa dapat menulis atau menggambar sesuatu pada modul. Untuk itu, pada modul telah dilakukan penyesuaian sesuai saran perbaikan tersebut dan hasil validasi menjukkan pada aspek Kegrafikan diperoleh nilai rata-rata 3.62 dengan kategori valid, sehingga tidak perlu revisi. Kemudian, pada aspek penyajian diperoleh nilai rata-rata 3,33 dengan kategori juga valid, sehingga tidak perlu revisi lagi. Nilai rata-rata tersebut menyatakan bahwa modul IPA yang dikembangkan sudah termasuk kategori "Baik". Selanjutnya, dalam aspek kebahasaan mendapatkan kriteria "Valid" sehingga tidak perlu revisi. Begitu juga dari penilaian oleh praktisi pendidikan mendapatkan kriteria "Valid" sehingga tidak perlu revisi/perbaikan.

\section{Uji Coba Kelayakan Produk}

Dalam proses uji coba kelayakan ini, peneliti bekerja sama dengan guru mempraktekkan Modul Eksperimen IPA untuk SD/MI yang Berbasis pada KPS dan Sikap Ilmiah pada Materi Sistem Peredaran Darah Manusia. Langkah yang dilakukan, pertama-tama peneliti membagikan modul Eksperimen IPA dan menerangkan bagaimana petunjuk menggunakan modul tersebut kepada peserta didik. Selanjutnya guru menerangkan materi "Sistem Peredaran Darah" dan meminta siswa berkelompok untuk mendiskusinya lebih lanjut. Selanjutnya, guna membuktikan materi yang dipelajari, maka siswa melakukannya dengan bereksperimen secara langsung menggunakan media barang bekas berupa botol-botol aqua.

Dalam proses melakukan kegiatan eksperimen tersebut, sebagaimana tujuan utama penggunaan modul Eksperimen IPA ini, maka yang menjadi perhatian utama adalah bagaimana siswa dapat memiliki pengetahuan sains (scientific knowledge), keterampilan proses (scientific process) dan sikap ilmiah (scientific attitude) yang baik. Untuk itu, pada saat penggalian pengetahuan (scientific knowledge) siswa diajak untuk berdiskusi secara aktif untuk mengkonstruksi pengetahuannya secara mandiri. Pada pengembangan keterampilan proses (scientific process), guru memastikan dengan teliti bahwa KPS mengobservasi, mengklasifikasi, mengukur, memprediksi, bereksperimen, mengkomunikasikan, dan menarik kesimpulan teroptimalisasi dalam diri siswa saat siswa melakukan eksperimen tersebut, sehingga dari itu sikap ilmiah (scientific attitude) siswa diyakini dapat terbentuk.

Setelah selesai melakukan kegiatan pembelajaran IPA di atas, selanjutnya siswa diminta mengisi angket untuk menunjukkan tanggapan/penilaian mereka terhadap kemenarikan modul tersebut. Dalam hal ini, angket berisi sejumlah pertanyaan dan siswa diminta memberikan tanggapan/jawabannya sesuai dengan kolom yang telah tersedia. Hasil perhitungan dari penilaian siswa tersebut menjadi dasar (data) untuk menilai apakah modul 


\section{MADRASAH}

Jurnal Pendidikan dan Pembelajaran Dasar

p ISSN: 1979-5599 | e ISSN: 2502-194X

P a ge

eksperimen IPA yang telah peneliti kembangkan tersebut menarik atau tidak. Berikut ini disajikan data hasil uji coba:

a. Uji Kelompok Kecil

Uji kelompok kecil dilaksanakan dengan jumlah siswa 20 orang. Hal ini merujuk pada pendapat Arief S. Sadiman (2012:184), uji coba sebaiknya dilakukan pada sampel dengan jumlah antara 10 - 20 orang yang mewakili populasi target. Pelaksanaan uji coba ini dilaksanakan sesuai jadwal mata pelajaran IPA di sekolah tersebut. Kesimpulan penilaian diperoleh nilai rata-rata 3.28, artinya modul yang dikembangkan termasuk kategori "Sangat Menarik".

b. Uji Kelompok Besar

Uji kelompok besar dilaksanakan dengan jumlah siswa 40 orang. Hal ini merujuk pada pendapat Arief S. Sadiman (2012:185) kembali, uji coba untuk kelompok besar sebaiknya dilakukan dengan jumlah sekitar 30 - 40 orang atau lebih dengan berbagai karakteristik sesuai dengan karakteristik populasi sasaran. Berdasarkan hasil penilaian diperoleh nilai rata-rata 3.27, artinya modul yang dikembangkan termasuk kategori "Sangat Menarik".

\section{Revisi Produk}

Berdasarkan hasil uji coba kelayakan produk Modul Eksperimen IPA untuk SD/MI diperoleh kesimpulan bahwa tanggapan peserta didik termasuk dalam kriteria "Sangat Menarik", sehingga dengan demikian tidak perlu dilakukan revisi atau perbaikan. Dengan pemberian penilaian tersebut, maka dapat dikatakan bahwa modul ini LAYAK dan MENARIK untuk digunakan sebagai bahan ajar dalam proses pembelajaran IPA di SD/MI, khususnya dalam pembahasan materi Sistem Peredaran Darah Manusia.

\section{PEMBAHASAN HASIL PENELITIAN}

Kegiatan penelitian ini menghasilkan Modul Eksperimen IPA untuk SD/MI. Modul merupakan bagian dari jenis bahan ajar. Menurut Andi Prastowo, yaitu modul merupakan bahan ajar yang disusun secara sistematis dengan bahasa yang mudah dipahami oleh siswa sesuai usia dan tingkat pengetahuan mereka agar mereka dapat belajar secara mandiri dengan bimbingan minimal dari pendidik (Andi Prastowo, 2012:106). Kemudian, Rudi Susilana dan Cepi Riyana mengemukakan modul merupakan suatu paket program yang disusun dan didesain sedemikian rupa untuk kepentingan belajar siswa (Rudi Susilana dan Cepi Riyana, 2008:14).

Dalam proses pengembangan modul IPA ini disajikan melalui kegiatan eksperimen. Hal ini sesuai dengan pendapat Gagne yang mengatakan "science should be viewed as a way of thinking in the pursuit of understading nature, as a waf of investigating claims about phenomena, and as a body of knowledge that has resulted from inquiry", yang artinya IPA harus dipandang sebagai cara berfikir dalam pencarian tentang pengertian rahasia alam dan sebagai batang tubuh pengetahuan yang dihasilkan dari proses inkuiri (penyelidikan).(Asih Widi Wisudawati, Eka Sulistyiwati, 2014:28).

Berdasarkan penjelasan di atas, alasan terpenting modul IPA disusun berbasis eksperimen agar siswa dapat mengerti fakta dan konsep IPA dengan lebih baik, belajar dengan berbuat secara langsung, bukan hanya menjadi penerima yang pasif namun memahami secara detail dan mendalam bagaimana proses IPA itu ditemukan melalui percobaan yang terstruktur secara ilmiah (Dirman dan Cicih Juarsih, 2014:137).

Selanjutnya, dalam desain modul, KPS menjadi unsur yang sangat penting sebab berdasarkan penelitian Hilal Aktamis dan Omer Ergin (2008) bahwa dengan perencanaan KPS (science process skill) dapat mendorong pada peningkatan kreatifitas dan prestasi akademik 
siswa yang lebih baik. Detailnya, dengan KPS; 1) Dapat membantu siswa menemukan dan membangun sendiri konsepsi. 2) Dapat memperdalam pemahaman konsep, karena dengan latihan keterampilan proses, siswa sendiri yang berusaha mencari dan menemukan konsep tersebut (Moedjiono dan Dimyati, 1992:150).

Abruscato mengklasifikasikan KPS menjadi dua bagian, yaitu keterampilan proses dasar (Basic Processes) dan keterampilan proses terintegrasi (Integrated Processes) (Eko Hadi Sujiono dan Khaeruddin, 2005:32). Sebagai bekal dasar, pertama siswa harus menguasai KPS dasar dan bila telah mampu dapat melanjutkan pada KPS berikutnya, sehingga penguasaannya padu dan menyeluruh (terintegrasi). Dalam bentuk gambar, berikut jalinan antar KPS.

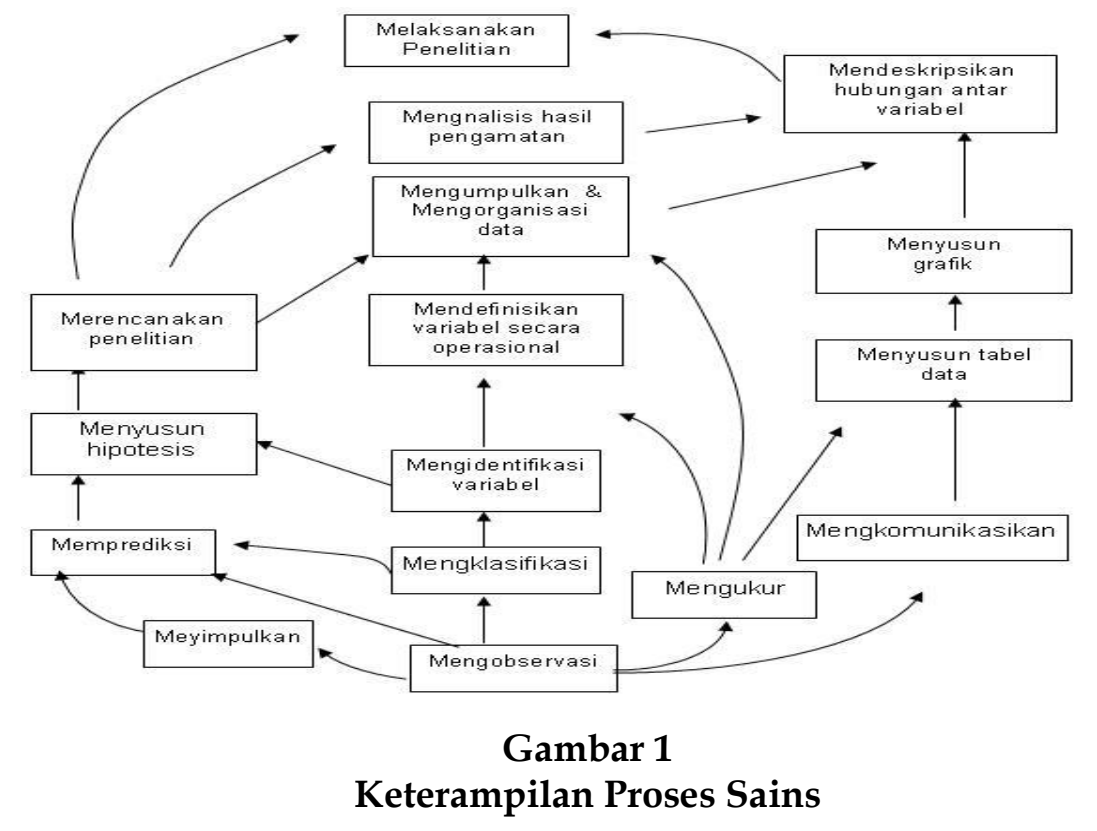

Untuk pelaksanaan KPS di Sekolah Dasar, penulis menyederhanakan pada beberapa KPS yang sifatnya masih mendasar dan penting dikuasai untuk tingkatan siswa SD/MI. Penjabaran KPS berikut dengan mengambil materi tentang Sistem Peredaran Darah Manusia, pelajaran untuk Kelas V.

1. Keterampilan Mengobservasi (observation)

Observasi merupakan KPS terpenting, sebab berawal dari hasil pengamatan yang cermat dan akurat akan diperoleh data (ilmu pengetahuan alam) yang faktual, rinci, relevan, dan memadai yang sangat dibutuhkan untuk melakukan penyelidikan ilmiah (the basic of all scientific inquiry is observation). Beberapa indikator dalam pelaksanaan KPS observasi: a) Menggunakan indera penglihatan, pembau, pendengar, pengecap, dan peraba pada waktu mengamati, b) Mengumpulkan fakta yang relevan dan memadai, c) Menghubungkan fakta yang ditemui dengan pengetahuan (teori), dan d) Memanfaatkan berbagai alat pengamatan yang sesuai.

Dalam proses ini, seharusnya siswa SD/MI dapat mengamati objek langsung amatan secara nyata alat-alat peredaran darah manusia, berupa jantung, pembuluh darah, dan darah. Namun hal tersebut tidak memungkinkan. Oleh karena itu hanya mengamati replika dan videonya. Fakta hasil pengamatan:

a. Jantung. Terletak dalam rongga dada agak ke sebelah kiri, besarnya lebih kurang satu kepal tangan, dengan berat sekitar 300 gram. Jantung senantiasa berdenyut dengan cara berelaksasi dan berkontraksi, sehingga jantung mengembang dan mengempis. Kemudian, jantung terdiri atas empat ruang, yaitu serambi kanan, serambi kiri, bilik kanan, dan bilik kiri. Di antara serambi kiri dan bilik kiri terdapat katup dua daun (valvula bikuspidalis), sedangkan di antara serambi kanan dan bilik kanan juga terdapat katup tiga daun (valvula trikuspidalis). 


\section{MADRASAH}

Jurnal Pendidikan dan Pembelajaran Dasar

p ISSN: 1979-5599 | e ISSN: 2502-194X

P a g e

b. Pembuluh darah. Berupa sebuah saluran untuk mengalirkan darah. Terbagi pada pembuluh nadi (arteri) dan pembuluh balik (vena). Pembuluh nadi tersusun atas lapisan luar yang bersifat elastis, lapisan tengah yang berupa sel-sel otot polos, dan lapisan dalam yang hanya disusun oleh selapis sel berdinding tipis. Sedangkan, pembuluh nadi memiliki dinding tebal, kuat, dan elastis untuk membantu memompa darah dari jantung. Pembuluh nadi memiliki pembuluh yang paling besar, yang disebut aorta. Pembuluh ini terletak pada pangkal pada bilik kiri jantung. Pembuluh ini memiliki cabang, yang mengarah ke atas dan satunya ke bawah. Selanjutnya, cabang-cabang tersebut bercabang-cabang lagi membentuk pembuluh nadi yang lebih kecil, yang disebut arteriol. Arteriol sangat tipis dan memiliki cabang lagi yang disebut pembuluh kapiler. Pembuluh kapiler mempunyai dinding yang sangat halus dan berdinding tipis bahkan lebih tipis dari pembuluh rambut. Selain itu, dinding pembuluh kapiler berpori dan tersusun dari selapis sel, serta diameternya sangat sempit sehingga hanya dapat dilalui oleh sel-sel darah satu per satu. Selanjutnya pembuluh balik (vena), juga terdiri dari tiga pembuluh, yaitu pembuluh balik atas, pembuluh balik bawah, dan pembuluh balik paru-paru. Pembuluh balik terletak dekat dengan permukaan tubuh dan tampak kebiru-biruan. Pembuluh vena mempunyai dinding yang lebih tipis dan tidak elastis. Pembuluh ini juga memiliki cabang-cabang yang disebut venula. Dengan demikian, jaringan pembuluh kapiler menghubungkan pembuluh nadi terkecil (arteriol) dan pembuluh vena terkecil (venula) untuk menuju ke jantung.

c. Darah. Berupa cairan berwarna merah, mulai dari merah terang hingga merah tua. Darah terdiri atas sel darah merah (eritrosit), sel darah putih (leukosit) dan keping darah (trombosit). Darah memiliki fungsi yang besar bagi manusia untuk mengangkut oksigen, membunuh kuman, mengedarkan sari-sari makanan, mengangkut sisa oksidasi, dan menjaga kestabilan suhu tubuh.

2. Keterampilan Mengelompokan (Classification)

KPS mengklasifikasi merupakan keterampilan mengelompokkan berbagai objek atau peristiwa dalam suatu sistematika tertentu. Berikut beberapa indikator KPS klasifikasi: a) Menunjukkan persamaan atau perbedaan antar dua subjek, b) Dapat mencari hubungan timbal balik dari hasil identifikasi persamaan dan perbedaan tersebut, c) Dapat mengkontraskan ciriciri, membandingkan, dan mencari dasar penggolongan berdasarkan kategori tertentu.

Dalam proses ini, siswa SD/MI didorong untuk membuat skema berupa persamaan atau perbedaan antar dua subjek, misalnya : a) Persamaan dan perbedaan antara serambi kanan dan serambi kiri dan antara bilik kanan dan bilik kiri; b) Persamaan dan perbedaan antara katup jantung valvula bikuspidalis, dan valvula trikuspidalis; c) Persamaan dan perbedaan antar pembuluh darah ; arteri, vena dan kapiler, dan d) Persamaan dan perbedaan antar darah yang berwarna merah terang dan merah tua.

Kemudian dari hasil identifikasi persamaan dan perbedaan tersebut, siswa SD/MI dapat menjelaskan hubungan timbal balik antara serambi kanan dan serambi kiri, bilik kanan dan bilik kiri, dan keberadaan antara katup jantung valvula bikuspidalis, dan valvula trikuspidalis, serta fungsi pembuluh darah; arteri, vena dan kapiler dalam proses sistem peredaran darah manusia. Selanjutnya, berdasarkan pemahaman tersebut, siswa SD/MI diharapkan dapat mengkontraskan ciri-ciri. Misalnya dalam hal ini ciri-ciri yang paling kontras (sangat berlawanan) apa antara pembuluh arteri, vena dan kapiler.

Dasar pengetahuan itu, selanjutnya menjadi bahan bagi siswa SD/MI untuk melakukan perbandingan dan menempatkan penggolongannya berdasarkan kategori tertentu, misalnya pembuluh nadi aorta adalah pembuluh yang lebih besar daripada pembuluh vena, dan pembuluh kapiler adalah pembuluh yang paling kecil dari pembuluh nadi ataupun vena, sehingga penggolongannya menurut ukuran, yang paling kecil adalah pembuluh kapiler, medium adalah pembuluh vena, dan paling besar adalah pembuluh nadi aorta. 


\section{Keterampilan Mengukur (Measurement)}

KPS mengukur merupakan aktivitas mengukur atau membandingkan suatu besaran yang diukur dengan satuan yang tepat. Indikator KPS mengukur; 1) Siswa mampu melakukan pengukuran menggunakan alat ukur yang baku (standard internasional) maupun non baku (standard konvenstional), misalnya dengan jengkalan tangan, benang, kayu, dan sebagainya, dan 2) Siswa dapat memilih satuan yang tepat sesuai dengan hasil pengukuran yang dilakukannya tersebut. Kaitannya dengan materi sistem peredaran darah, hal sederhana yang dapat dilakukan siswa SD/MI, misalnya:

a. Menghitung denyut nadi. Denyut nadi adalah berapa kali pembuluh nadi arteri berelaksasi dan berkontraksi dalam 1 menit terhadap detak jantung. Jadi mengukur jumlah denyut nadi sama dengan mengukur kecepatan denyut jantung. Denyut nadi pada manusia, normalnya berkitar 60-100 kali dalam 1 menit. Contoh perhitungan dengan standar baku, seperti menggunakan stetoskop dan contoh perhitungan dengan standar non baku, yakni dengan menempelkan ibu jari kanan pada pergelangan tangan kiri atau bisa juga pada sisi samping leher kiri atau kanan bagian depan.

b. Menghitung tekanan darah. Tekanan darah adalah tekanan yang terjadi pada pembuluh nadi (arteri) ketika jantung memompa darah untuk dialirkan ke seluruh tubuh. Pada manusia, normalnya berkitar antara $120 / 80 \mathrm{mmHg}$. Contoh perhitungan tekanan darah dengan standar baku, seperti menggunakan tensimeter atau sphygmomanometer.

4. Keterampilan Meramalkan (Prediction)

Prediksi adalah ramalan atau dugaan tentang kejadian atau keadaan yang akan terjadi di masa akan datang. Melakukan prediksi didukung data dan fakta yang akurat hasil dari kegiatan KPS sebelumnya. Beberapa indikasi KPS prediksi, yakni: 1) Siswa mampu mencari atau menemukan pola hubungan atau kecenderungan berdasarkan bukti (data, fakta, konsep keilmuan, dan informasi) yang dimilikinya saat ini dengan bukti yang telah ditemukannya sebelumnya, 2) Berdasarkan pola hubungan atau kecenderungan tersebut, siswa dapat mengajukan perkiraan tentang sesuatu, peristiwa, kejadian yang akan terjadi di masa akan datang.

Berdasarkan pengetahuan dan data kegiatan sebelumnya diketahui bahwa sistem peredaran darah manusia merupakan suatu siklus yang berulang dan kompleks, dimana jantung berperan sentral sebagai pusat pemompa untuk mengalirkan darah bersih yang kaya oksigen ke seluruh jaringan tubuh. umumnya darah yang sehat berwarna merah pekat terang karena menandakan dalam cairan darah lebih banyak mengandung oksigen.

Dalam kondisi normal, peredaran darah manusia akan berjalan sesuai teori yang dikemukakan di atas. Namun pada kondisi sekarang, dimana udara sudah banyak terpapar oleh zat-zat yang berbahaya sehingga manusia akan kesulitan mendapatkan oksigen (udara yang bersih). Karena itu siswa dapat menerka apa yang akan terjadi di masa akan datang jika kondisi ini terus berlanjut, terlebih jika kadar polusi udara semakin parah.

5. Keterampilan Melakukan Percobaan Sederhana

Percobaan (eksperimen) merupakan kegiatan yang dilakukan guna menjawab, menguji atau membuktikan prediksi yang telah dibuat siswa sebelumnya. Indikator penguasaan KPS ini, meliputi 1) Kemampuan dalam menentukan alat, bahan, dan sumber yang akan digunakan dalam percobaan, 2) Menentukan variable atau objek yang akan diteliti, 3) Memahami cara dan langkah-langkah kerja dalam pelaksanaan percobaan.

Percobaan ini dilakukan untuk menjawab pertanyaan yang telah diajukan dalam KPS prediksi. Pada percobaan ini digunakan hewan burung, sebab sebagaimana manusia, burung sama-sama bernafas menggunakan paru-paru. Dalam percobaan ini dibutuhkan dua ekor burung; satu ditempatkan di udara bersih dan satu ekornya pada udara kotor. Lama proses uji coba \pm 1 bulan.

Hasil pembuktian, diketahui burung yang ditempatkan di udara bersih, paru-paru burung berwarna merah terang-pekat, sedangkan burung pada yang ditempatkan di udara kotor paru-parunya berwarna putih pucat. Penjelasannya sederhana, dalam proses peredaran 


\section{MADRASAH}

Jurnal Pendidikan dan Pembelajaran Dasar

p ISSN: 1979-5599 | e ISSN: 2502-194X

P a g e

darah manusia, bernafas dimulai ketika manusia menghirup udara (oksigen) melalui hidung dan masuk ke dalam paru-paru. Setelah berada di paru-paru, darah berisi oksigen lalu masuk ke jantung melalui serambi kiri lalu ke bilik kiri. Selanjutnya, di dalam jantung darah kemudian dipompa untuk dialirkan menuju ke seluruh tubuh melalui pembuluh nadi aorta. Pembuluh nadi aorta bercabang dua, cabang yang ke arah atas untuk mengalirkan darah ke bagian tangan, kepala, dan leher dan cabang yang menuju ke arah bawah untuk mengalirkan darah ke bagian bawah tubuh (body dan kaki).

Darah yang telah diedarkan ke seluruh tubuh, selanjutnya mengalir kembali ke paruparu (sebelum masuk ke jantung) melalui serambi kanan lalu ke bilik kanan. Namun darah yang telah diedarkan ke seluruh tubuh tersebut, kandungan darahnya tidak lagi mengandung banyak oksigen, namun lebih banyak mengandung karbondioksida. Oleh karena itu, untuk membersihkannya, darah yang banyak mengandung karbondioksida tersebut, diambil dan diganti dengan oksigen melalui proses pernafasan kembali. Namun jika udara yang dihirup juga masih mengandung polusi, maka jantung akan bekerja lebih keras untuk memompa darah guna menghasilkan darah yang kaya dengan oksigen dan hal ini dapat memicu gangguan pada jantung dan paru-paru.

Kesimpulannya, berdasarkan temuan hasil percobaan di atas, siswa dapat membuktikan dugaan (prediksinya) benar, yakni jika manusia (yang dicontohkan dengan hewan burung) dalam bernafas lebih banyak menghirup udara kotor, maka peredaran darah akan terganggu, tersumbat. Indikasi nyata dapar terlihat nyata pada warna paru-paru. Pada paru-paru yang menyerap udara bersih cenderung merah-terang pekat, sementara yang menyerap udara kotor agak putih pucat.

6. Keterampilan Penarikan Kesimpulan

Menyimpulkan adalah keterampilan membuat ikhtisar berdasarkan data dan fakta hasil pengamatan dan percobaan yang telah dilakukan sebelumnya. Kesimpulan percobaan ini yaitu sistem peredaran darah manusia dapat diartikan sebagai proses menyalurkan darah ke seluruh tubuh manusia. Proses tersebut dapat terjadi karena adanya jantung yang berperan sebagai pemompa darah dan pembuluh darah sebagai saluran penghantar darah. Jantung berdenyut dengan cara berelaksasi dan berkontraksi. Jantung memiliki empat ruang, yaitu serambi kanan, serambi kiri, bilik kanan, dan bilik kiri. Di antara serambi kiri dan bilik kiri terdapat katup dua daun (valvula bikuspidalis), sedangkan di antara serambi kanan dan bilik kanan terdapat katup tiga daun (valvula trikuspidalis). Denyut jantung pada manusia, normalnya berkitar 60-100 kali dalam 1 menit. Cara mengetahuinya, dapat dengan cara sederhana maupun menggunakan alat berupa stetoskop.

Dalam proses peredaran darah manusia, peran paru-paru sangat penting mensuplai oksigen ke dalam darah. Darah manusia berwarna antara merah terang sampai merah tua. Warna merah terang menunjukkan udara yang dihirup banyak mengandung oksigen. Dalam keseharian, jika manusia dalam bernafas lebih banyak menghirup udara kotor, maka jantung akan bekerja lebih keras dan ini dapat memicu denyut jantung berdetak lebih kuat. Dampaknya kesehatan jantung bisa terganggu, seperti dapat tiba-tiba mengalami jantung koroner, gagal ginjal, diabetes, hipertensi (tekanan darah tinggi), dan lainnya. Pada manusia, tekanan darah normalnya berkitar antara $120 / 80 \mathrm{mmHg}$. Untuk menghitungnya harus menggunakan alat berupa tensimeter atau sphygmomanometer.

Dalam pandangan agama Islam, dalam ayat-ayat al-Qur'an banyak ditemukan ayat yang mengatur tentang menjaga kesehatan jantung seperti dalam QS Al-Isra ayat 36, Qs. AlQaaf:16, dan Qs. Al-Haaqah:45-46. Hikmahnya bahwasanya sifat religious dan spiritual pembahasan tentang peredaran darah, mulai dari jantung, pembuluh darah, dan darah secara medis dan kedokteran dapat dipertanggung jawabkan keilmiahan secara logika (akal sehat) dan kebenarannya dapat dibuktikan nyata dalam kehidupan sehari-hari. 
Pada tahapan selanjutnya, pada substansinya ketika siswa melakukan kegiatan eksperimen dengan mengikut prosedur KPS, sebenarnya siswa berlatih bersikap layaknya para ilmuwan sains dalam menemukan fakta-fakta dan membangun keterhubungan antar konsepkonsep guna mencari berbagai jawaban atas persoalan-persoalan yang dihadapinya melalui kemampuan bernalar dan berkreatifitas yang dimilikinya. Fakta ini dikuatkan oleh dengan pendapat Noll (1935, dalam Nath, Streetanuka dan Sybil Thomas, 2012:38) yang menyatakan sikap ilmiah mendorong siswa untuk terbiasa berfikir dalam beberapa hal berikut : a) Habit of accuracy in all operations including accuracy in calculation and report; b) Habit of intellectual honesty;c) Habit of open mindedness; d) Habit of open suspended judgement; e) Habit of looking for true couse and effect relionship; dan f) Habit of criticalness, including that of self-critism.

Dalam konteks demikian, terjadi peningkatan retensi kemampuan untuk mengembangkan sikap ilmiah siswa (Sari Prima Mutia, 2013:32). Selanjutnya, keterlibatan siswa secara aktif baik fisik maupun mental dalam kegiatan eksperimen (percobaan sederhana) juga akan membawa pengaruh terhadap pembentukan pola tindakan siswa yang selalu didasarkan pada hal-hal yang bersifat ilmiah. Menurut Brotowidjoyo, orang yang berjiwa ilmiah adalah orang yang memiliki sikap-sikap berikut: a) Sikap ingin tahu; b) Sikap berani mempertahankan kebenaran; c) Sikap kritis; d) Sikap terbuka; e) Objektif; f) Rela menghargai karya orang lain; dan g) Bersikap "futuristik". (Karkami, 2000:12)

Kemudian, Asih Widi Wisudawati dan Eka Sulistyiwati menambahkan sikap ilmiah IPA yang terbentuk yaitu: a) Sikap respek terhadap data/fakta; b) Sikap penemuan dan kreatifitas; c) Sikap berpikiran terbuka dan kerjasama; dan d) Sifat peka terhadap lingkungan sekitar. (Asih Widi Wisudawati, Eka Sulistyiwati, 2014:24-25). Kemudian, sikap ilmiah yang juga ditumbuhkembangkan yaitu sikap ilmiah pantang menyerah atau selalu ingin mencoba, bertanggung jawab, dan mampu bekerjasama.

\section{E. KESIMPULAN DAN SARAN}

Kesimpulan penelitian Research and Development $(R \mathcal{E} D)$ ini adalah pengembangan modul eksperimen IPA untuk SD/MI berbasis pada KPS dan sikap ilmiah pada materi Sistem Peredaran Darah Manusia LAYAK dan MENARIK untuk digunakan. Penilaian ini diperoleh dari hasil penilaian validator dan praktisi pendidikan, serta respon kemenarikan dari siswa. Untuk itu, saran penelitian ini untuk peneliti berikutnya, agar dapat melakukan penelitian hingga pada tahap uji pemakaian dan produksi masal dari produk yang sudah dihasilkan, serta materi yang dikembangkan diperluas lagi.

\section{REFERENSI}

Aktamis, Hilal dan Omer Ergin, (2008). The Effect of Scientific Process Skills Education on Students' Scientific Creatifity, Science Attitude and Academic Achievements. Asia Pacific Forum on Science Learning and Teaching, Volume 9, Issues 1, Article 4.

Borg \& Gall, (1983), Education research: An Introduction, Longman Edisi 2, McKay University of Wisconsin-Madison, New York.

Carin, Artur A \& Robert B. Sund (1989). Teaching science through discovery. Sixth edition. Columbus. Charles E. Merrill Publishing Company

Depdiknas. (2007). Panduan Pengembangan Pembelajaran IPA Terpadu. Jakarta: Puskur, Balitbang Depdiknas

Dirman dan Cicih Juarsih, (2014). Teori Belajar dan Prinsip-prinsip Pembelajaran yang Mendidik, Jakarta: Rineka Cipta.

Karhami, K. A. (2000). Sikap Ilmiah Sebagai Wahana Pengembangan Unsur Budi Pekerti (kajian melalui sudut pandang pengajaran IPA). Jurnal Pendidikan dan Kebudayaan, No.027, Tahun ke-6, November.

Koballa \& Chiapetta. (2010). Science Instruction in the Middle and Secondary School Pearson: USA

Moedjiono dan Dimyati, (1992). Strategi Belajar Mengajar, Jakarta: Dipartemen Pendidikan Direktorat Jendral Pendidikan Tinggi Direktorat Ketenagaan

Vol. 11 No. 1 Desember 2018

Madrasah homepage: http://ejournal.uin-malang.ac.id/index.php/madrasah/index 


\section{MADRASAH}

Jurnal Pendidikan dan Pembelajaran Dasar

p ISSN: 1979-5599 | e ISSN: 2502-194X

Nath, Streetanuka dan Sybil Thomas. (2012). Enhancing Science Process Skills and Scientific Attitute and Analysing their Interactions: An Intervention through Inquiry Learning Approach. Internatuonal Journal of Scientific Reasearch, ISSN No. 2277-8179. Volume 1, Issues 1, June, h. 37-42

Novitasari, (2014). "Pengembangan Lembar Kerja Siswa (LKS) untuk Mengoptimalkan Praktikum Virtual Laboratory Materi Induksi Elektromagnetik". Prosiding Seminar Nasional Pendidikan IPA 2014: Di UIN Syarif Hidayatullah Jakarta tanggal 11 September 2014).

Prastowo, Andi. (2014), Pengembangan Bahan Ajar Tematik, Jakarta: Kencana.

Prastowo, Andi. (2012). Panduan Kreatif Membuat Bahan Ajar Inovatif. Yogyakarta: Diva Press

Sabri, Ahmad, (2005), Strategi Belajar Mengajar dan Micro Teaching, Ciputat: Ciputat Press

Samatowa, Usman. (2006). Bagaimana Membelajarkan IPA di Sekolah Dasar. Jakarta: Direktorat Pendidikan Nasional

Sari, Prima Mutia, (2013). Pengaruh Model Pembelajaran Berbasis Praktikum terhadap Keterampilan Proses Sains, Sikap Iilmiah dan Penguasaan Konsep Sistem Regulasi. Thesis Universitas Pendidikan Indonesia, Bandung.

Suamntri, M dan Permana, J. (2001) Strategi Belajar Mengajar. Bandung: CV Maulana.

Sugiyono, (2013). Metode Penelitian Pendidikan Pendekatan Kuantitatif, Kualitatif, dan RED, Bandung: Alfabeta

Sujiono, Eko Hadi dan Khaeruddin. (2005). Modul Fisika SMA pada Pendidikan E Latihan Profesi Guru. Penyelenggara Sertifikasi Guru Rayon 24 Universitas Negeri Makassar

Sukiman. (2011). Pengembangan Media Pembelajaran. Yogyakarta: Pustaka Insan Madani

Sukmadinata, Nana Syaohdih, (2012). Metode Penelitian Pendidikan, Bandung: Remaja Rosdakarya.

Susilana, Rudi dan Cepi Riyana. (2008). Media Pembelajaran. Bandung: Wacana Prima

Trianto, (2013). Model Pembelajaran Terpadu, Surabaya: Bumi Aksara.

Winataputra, Udin.S. (1992). Strategi Belajar Mengajar IPA. Jakarta: Universitas Terbuka.

Wisudawati, Asih Widi dan Eka Sulistyowati, (2014). Metodologi Pembelajaran IPA, Jakarta: Bumi Aksara. 


\section{PANDUAN PENULISAN \\ MADRASAH: JURNAL PENDIDIKAN DAN PEMBELAJARAN DASAR \\ FAKULTAS ILMU TARBIYAH DAN KEGURUAN \\ UNIVERSITAS ISLAM NEGERI MAULANA MALIK IBRAHIM MALANG}

\section{Umum}

1. Karya ilmiah harus asli, belum pernah dipublikasikan di media lain, atau sedang dalam proses review untuk diterbitkan di publikasi lain (melampirkan surat pernyataan).

2. Menggunakan Bahasa Indonesia atau Bahasa Inggris* (*Pastikan penulisan dengan Bahasa Inggris sesuai kaidah yang berlaku, dan disubmit online melalui http://ejournal.uin-malang.ac.id/index.php/madrasah, kami tidak bertanggung jawab jika artikel anda tidak mendapat respon dari reviewer)

3. Menggunakan kertas A4 $(21 \mathrm{~cm} \times 29.7 \mathrm{~cm})$, dengan margin kiri $2.5 \mathrm{~cm}, 2 \mathrm{~cm}$ kanan, $2 \mathrm{~cm}$ bawah, $2 \mathrm{~cm}$ atas.

4. Jumlah paper minimal 7 halaman, maksimal 16 halaman kecuali ada lampiran, toleransi maksimal 20 halaman dengan 1 spasi dan alignment justify.

5. Font yang digunakan Book Antiqua 12 pt dan Sakkal Majalla (Jika ada konten Bahasa Arab) 14 pt.

6. Disarankan menggunakan referensi yang terbaru 10 tahun terakhir, kecuali kitab klasik.

7. Format file menggunakan Mic. Office/open Office (disarankan office 2013/2016_ dengan eksistensi RTF bukan PDF.

\section{Kontent Naskah}

1. Judul maksimal 15 kata, alignment center.

2. Nama penulis tidak menggunakan gelar, mencantumkan institusi, dan email.

3. Abstrak minimal $150 \mathrm{kata}$ dan maksimal $300 \mathrm{kata}$, satu paragraph, tidak terdapat tabel dan gambar.

4. Keywords minimal 3 kata dan maksimal 5 kata, dipisahkan dengan tanda titik koma $(;)$.

5. Sistematika penulisan: Judul, Abstrak, Kata Kunci, Pendahuluan, Metode, Hasil, Pembahasan, Simpulan dan Saran, Pernyataan Terima Kasih (jika ada), Daftar Rujukan. Selain hasil riset, menyesuaikan dengan format penulis.

6. Format Tabel (Bold). Jika terdapat tabel, jarak antara row adalah 1 spasi, pada kategori tabel huruf ditebalkan (bold), dan penulisan sumber setelah tabel terakhir. Jika tabel bersambung ke halaman berikut blok row kategori tabel dengan kemudiak klik layout $=>$ repeat header rows seperti format tabel A.1.

Tabel A.1 Judul Tabel (justify)

(1 spasi)

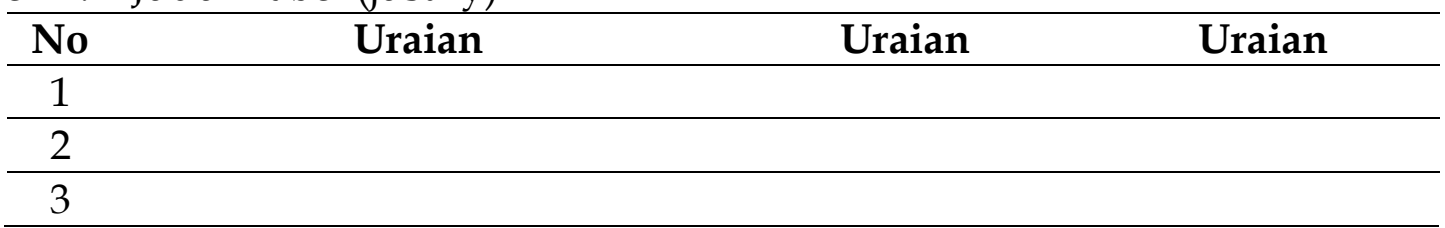

Sumber: 


\section{Format Gambar}

Jika terdapat gambar, grafik, diagram, dan yang serupa gunakan format dan wrap text gambar $=>$ in line with text atau menggunakan fitur text box, untuk kestabilan terhadap perubahan format dan pergesaran. Jarak antara kalimat terakhir dan sesudah gambar adalah 1 spasi. Gambar posisi center (tengah) seperti gambar A.1. (1 spasi)

Gambar A.1 Judul Gambar (center)

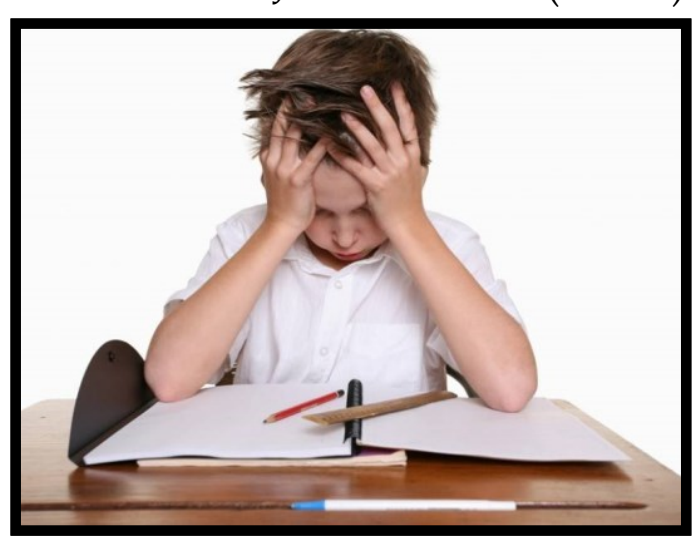

Sumber: (center)

(1 spasi)

\section{Format Numberring}

Pada jurnal Madrasah tidak diperkenankan menggunakan Bullet hanya Numberring, kecuali termasuk dalam penulisan rumus. Numbering menggunakan format Huruf dan Angka. Dimulai dari Huruf kemudian Angka seperti format berikut.

Format Numbering:

A.

1.

2.

a.

b.

1)

2)

a)

b)

B.

C.

9. Daftar Kutipan dan Rujukan menggunakan format APA 6 $^{\text {th }}$ Style Edition. Disarankan menggunakan aplikasi referensi seperti Zotero, Mandeley, Endnote, dan sebagainya.

10. Sebelum mengirim naskah, disarankan untuk melakuken cek typographical dan grammatical errors serta cek plagiat, bisa melalui.

a. Grammarly: www.grammarly.com 
b. Turnitin: http://turnitin.com/

11. Contatc:
a. Website : http://ejournal.uin-malang.ac.id/index.php/madrasah
b. Email : madrasah@uin-malang.ac.id
c. Editor in Chief: M. Irfan Islamy (085390790907)

\section{Author Fees}

This journal charges the following author fees.

Article Submission: 0 (IDR)

Fast-Track Review: 0 (IDR)

Article Publication: 0 (IDR)

Open Donations:

\section{Copyright Notice}

Madrasah: Jurnal Pendidikan dan Pembelajaran Dasar

\section{Privacy Statement}

The names and email addresses entered in this journal site will be used exclusively for the stated purposes of this journal and will not be made available for any other purpose or to any other party. 
UCAPAN TERIMAKASIH

KEPADA PARA REVIEWER, EDITOR, DAN PENULIS ATAS TERBITNYA MADRASAH: JURNAL PENDIDIKAN DAN PEMBELAJARAN DASAR VOLUME 11 NOMOR 1 DESEMBER 2018 